\title{
Growth and biochemical composition of Spirulina platensis dry biomass in diluted monosodium glutamate waste waters
}

\begin{abstract}
Wardah Wardah ${ }^{1}$, Finalah Nurhayati ${ }^{2}$, Mery Maria Magdalena ${ }^{2}$, Nur Fazilah ${ }^{2}$, Tatang Sopandi ${ }^{2}$
${ }^{1}$ Study Program of Agroindustry, Faculty of Vocational, University of 17 Agustus 1945 Surabaya. Jl. Semolowaru 45, Surabaya, East Java, Indonesia

${ }^{2}$ Study Program of Biology, Faculty of Science and Technology, University of PGRI Adi Buana, Surabaya. Jl. Dukuh Menanggal XII, 60234, Surabaya, East Java, Indonesia

Abstract

The use of low-cost culture media is important for the development of large-scale Spirulina platensis production. This study aims to investigate the effects of using diluted monosodium glutamate wastewater (MSGW) as a culture medium on the growth and biochemical composition of $S$. platensis dry biomass. Nitrogen and phosphorus uptake by $S$. platensis from MSGW media was also investigated in this study. Four concentrations of MSGW have been used in this study, namely 1.5, 2.5, 3.5 and $4.5 \mathrm{~mL} / \mathrm{L}$ and Walne medium was used as a control. All media were adjusted at $\mathrm{pH} 9$ and S. platensis culture was carried out for 14 day at $36.0^{\circ} \mathrm{C}, 77 \%$ relative humidity, 5000 lux light intensity and aeration rate at $0.7 \mathrm{~L} / \mathrm{min}$. The results of this study have indicated that the growth, protein, lipids, carbohydrates and chlorophyll of $S$. platensis biomass at $2.5 \mathrm{~mL} / \mathrm{L}$ MSGW concentrations were not significantly different from Walne medium, but were significantly different from 1.5, 3.5 and 4.5 $\mathrm{mL} / \mathrm{L}$ MSGW concentrations. The present study have also shown those nitrogen and phosphorus uptakes by $S$. platensis from $2.5 \mathrm{~mL} / \mathrm{L}$ MSGW concentration was not significantly different from Walne medium, but were significantly different from 1.5, 3.5 and $4.5 \mathrm{~mL} / \mathrm{L}$ MSGW concentrations. The present study concluded that $S$. platensis can be cultivated in MSGW as a medium with an optimum concentration of $2.5 \mathrm{~mL} / \mathrm{L}$. This finding will serve as a basic reference for future studies to utilize MSGW for microalgae culture media.
\end{abstract}

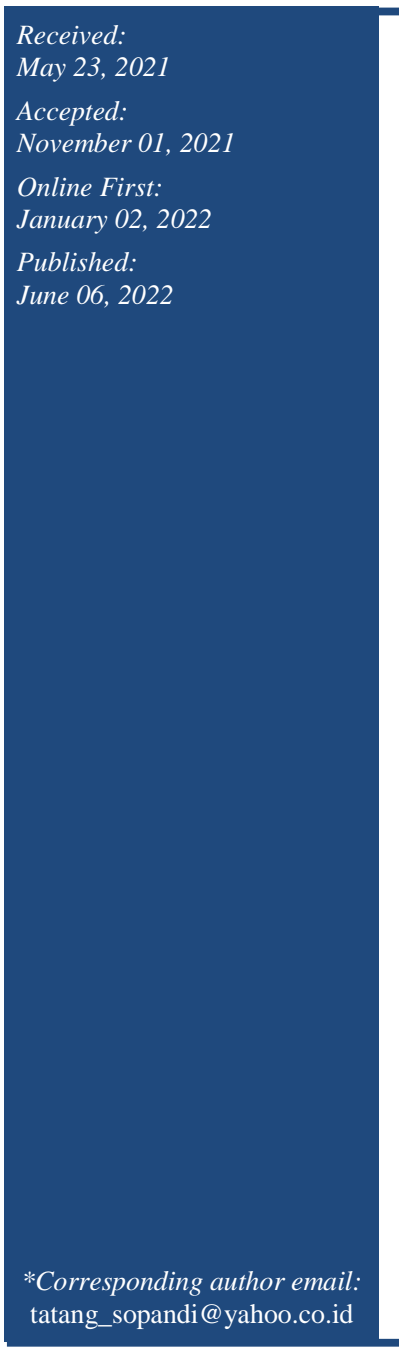

Keywords: Biomass, Biochemical, Monosodium glutamate wastewater, Spirulina platensis

How to cite this:

Wardah W, Nurhayati F, Magdalena MM, Fazilah N and Sopandi T, 2022. Growth and biochemical composition of Spirulina platensis dry biomass in diluted monosodium glutamate waste waters. Asian J. Agric. Biol. 2022(3): 202105220. DOI: https://doi.org/10.35495/ajab.2021.05.220.

This is an Open Access article distributed under the terms of the Creative Commons Attribution 3.0 License. (https://creativecommons.org/licenses/by/3.0), which permits unrestricted use, distribution, and reproduction in any medium, provided the original work is properly cited.

\section{Introduction}

An increase in the human population to 9.1 billion in 2050 requires an enlargement in food production of about $70 \%$ (Food and Agriculture Organization, 2009). Limitations and changes in the function of 
agricultural land is a challenge to achieve increased food production. Microalgae is currently being promoted as a new food source rich in vitamins, minerals, proteins, polyunsaturated fatty acids and antioxidants (Pareek, 2016). Microalgae also have advantages in terms of production efficiency compared with other protein sources such as mammals; it can consume light energy and inorganic nutrients to produce nutrient-rich biomass such as lipids, carbohydrates, proteins and pigments (Markou and Nerantzis, 2013).

Spirulina is an important and popular microalgae for cultivation. The commercial production of Spirulina continues to increase in worldwide for use in human food supplements, animal feed and pharmaceuticals (Madkour et al., 2012). Spirulina platensis is the most widely cultivated species and is widely available in the world (Delrue et al., 2017). $S$. platensis is also used as raw material for various products such as biodiesel (Rahman et al., 2017), functional food (Fithriani and Sinurat, 2019), cosmetics and thalassotherapy (Mourelle et al., 2017).

S. platensis can be cultivated, harvested and processed easily and has very high macro and micronutrient reserves (Habib et al., 2008). However, to increase the efficiency and profitability of $S$. platensis cultivation, it is necessary to reduce production costs. The cost of media is considered the second major factor that influences the cost of $S$. platensis production after labor (Vonshak, 1997). S. platensis can directly utilize mineral elements for its growth; therefore the composition and biomass productivity are highly dependent on the availability of nutrients in the culture medium especially nitrogen and phosphate (Delrue et al., 2017). Zarrouk and Walne media have successfully served as the standard medium for $S$. platensis culture for many years including in Indonesia. Nevertheless, both Zarrouk and Walne media are relatively expensive with limited availability for $S$. platensis farmers in Indonesia, which has an impact on the development of the $S$. platensis culture industry. Therefore, it is necessary to find a source of alternative nutrition media that is cheap and easy to obtain for S. plantesis cultivation such as from agricultural and industrial waste. From livestock waste such as goat manure (Sopandi et al., 2020) and quail manure (Samudera and Sopandi, 2020) with concentrations of 75 and $100 \mathrm{~g} / \mathrm{L}$ respectively, it is known that it can be used as a culture medium for $S$. platensis to replace
Zarrouk medium.

Several wastewaters are recognize as potential nutrient sources for microalgae and $S$. platensis culture, as well as municipal, industrial and agroindustrial wastewaters (Cai et al., 2013). Utilization of the monosodium glutamate wastewaters (MSGW) factory is one alternative to overcome the limitations of $S$. platensis culture media. Production of monosodium glutamate (MSG) in Indonesia reaches 515,600 tons per year (Citra Cendikia Indonesia, 2021). MSGW production data in Indonesia is not available in various publications, but is estimated to be quite abundant at low prices. For example, two MSG companies, namely PT Indomiwon Citra Inti and PT Ve Wong Budi Indonesia, each produce MSGW of around 250,000 300,000 L/day and 100,000-200,000 L/day at a selling price of $0.0043-0.0071 / \mathrm{L}$ US dollar (Soelaeman et al., 2004).

MSGW has been reported to be used as fertilizer for corn (Singh et al., 2011) and lettuce crops (Haghighi et al., 2015). It was also reported that addition of monosodium glutamate powder to the culture medium can accelerate the growth of Spirulina (Prabha et al., 2016). Hence, this study aims to investigate the effects of using diluted MSGW as a culture medium on the growth and biochemical composition of $S$. platensis dry biomass. Nitrogen and phosphorus uptake by $S$. platensis from MSGW media were also investigated in this study.

\section{Material and Methods}

\section{Experimental design}

This study was conducted using a completely randomized experimental design with 5 treatments of MSGW concentration in $S$. platensis culture medium. The treatments consisting of $0,1.5,2.5,3.5$ and 4.5 $\mathrm{mL} / \mathrm{L}$ of MSGW in distilled water were replicated 5 times. As a control ( $0 \mathrm{~mL} / \mathrm{L}$ MSGW), Walne medium was used.

\section{Culture of Spirulina platensis}

Monosodium glutamate wastewater (MSGW) has been obtained from PT. Miwon, Mojokerto, Indonesia, a food-flavoring monosodium glutamate (MSG) factory. In this study, S. platensis was cultured in distilled water containing various concentrations of MSGW and Walne medium was used as a control. A total of $5 \mathrm{~L}$ of distilled water was divided into 4 parts of $1.25 \mathrm{~mL}$ each, then added 
$1.875,3.125,4.375$ and $5.625 \mathrm{~mL}$ of MSGW in each part to obtain concentrations of 1.5, 2.5, 3.5 and 4.5 $\mathrm{mL} / \mathrm{L}$ MSGW in in $S$. platensis culture medium. Then to each concentration of MSGW was added $0.2 \%$ sodium chloride $(\mathrm{NaCl})$ until salinity $15 \%$, gradually added sodium bicarbonate $\left(\mathrm{NaHCO}_{3}\right)$ to $\mathrm{pH}$ 9 and $0.5 \mathrm{~g}$ of cyanocobalamin. After homogenizing, from each concentration of MSGW divided by 5 parts and each part $(250 \mathrm{~mL})$ then put into a $500 \mathrm{~mL}$ Erlenmeyer flask. A total of $50 \mathrm{~mL}$ was taken from every $250 \mathrm{~mL}$ of each MSGW concentration for heavy metal analysis. The preparation of $1000 \mathrm{~mL}$ Walne culture medium was carried out as directed by Andersen (2005). Each medium was prepared was poured into Erlenmeyer flask $(500 \mathrm{~mL})$, followed by adding $50 \mathrm{~mL} / \mathrm{L}(1.36 \mathrm{~g} / \mathrm{L}$ dry biomass $)$ of $S$. platensis brood stock and stirred homogeneously. The $S$. platensis brood stock was obtained from the Center for Brackish Water Aquaculture, Jepara, Central Java, which was cultivated at the Biology Laboratory, Faculty of Sciences and Technology, University of PGRI Adi Buana, Surabaya. Culture of S. platensis was performed for 14 day at $36^{\circ} \mathrm{C}, 77 \%$ relative humidity, 5000 lux light intensity and aeration using aquarium air pump (SONIC P-125, 85 $\mathrm{L} / \mathrm{min}, 0.04 \mathrm{MPa}$ ) with standardized aeration rate at $0.7 \mathrm{~L} / \mathrm{L} / \mathrm{min}$.

\section{Concentration of heavy metal}

Heavy metal concentration in MSGW culture medium such as magnesium $(\mathrm{Mg})$, iron $(\mathrm{Fe})$, manganese $(\mathrm{Mn})$, cuprum $(\mathrm{Cu})$ and Zinc $(\mathrm{Zn})$ were measured before culture using the atomic absorption spectrometry (AAS) (Shimadzu AA 700) method based on Smith (1983). All chemicals of high purity analytical grade reagents were employed; nitric acid $\left(\mathrm{HNO}_{3} 69 \%\right)$ and hydrochloric acid $(\mathrm{HCl} 37 \%)$ from Merck, Germany were used for both extraction and acid digestion procedures. Standard solutions of $\mathrm{Mg}$, $\mathrm{Mn}, \mathrm{Fe}, \mathrm{Cu}$ and $\mathrm{Zn}$ (Merck, Germany) in $1000 \mathrm{mg} / \mathrm{L}$ each were diluted in series with $\mathrm{HNO}_{3} 0.5 \mathrm{~mol} / \mathrm{L}$ to obtain concentrations of $2,4,8,10,12,14,16,18$ and $20 \mathrm{ppm}$ and used as stock solutions. The optical density of the samples was observed using AAS at wavelengths 285.2, 248.3, 279.5, 249.2 and $213.9 \mathrm{~nm}$ for $\mathrm{Mg}, \mathrm{Fe}, \mathrm{Mn}, \mathrm{Cu}$ and $\mathrm{Zn}$ respectively.

\section{Concentration of nitrogen}

Ammonium nitrogen $\left(\mathrm{NH}_{4}{ }^{-} \mathrm{N}\right)$ concentration in culture medium was measured before and after cultivation (residue) using the method based on
American Society of Agronomy and Soil Science Society of America (1982). All chemicals for nitrogen analysis from high purity analytical grade reagents (Merck, Germany). The optical density of samples was measured at $636 \mathrm{~nm}$. Ammonium sulfate $\left(\left(\mathrm{NH}_{4}\right)_{2} \mathrm{SO}_{4}\right)$ was used to prepare nitrogen standards.

\section{Concentration of phosphorus}

Phosphorus concentration in media was conducted at before and after cultivation (residue) and was determined using the spectrophotometer method based on Standard National Indonesia (2010). All chemicals for phosphorus analysis from high purity analytical grade reagents (Merck, Germany). The optical density of samples was measured every minute for $1 \mathrm{~h}$ at $400 \mathrm{~nm}$. Phosphorous 7723-14-0 was used to prepare phosphorous standards solution with concentrations of $0,2,4,6,8,10 \mathrm{mg} / \mathrm{L}$ in molybdate-vanadate solution and their optical density measured at $395 \mathrm{~nm}$.

\section{Growth of Spirulina platensis}

Spectrophotometer method at a wavelength of 680 nm (Yap et al., 2018) was used to observe the daily growth of S. platensis. Before measuring the optical density, $1 \mathrm{~mL}$ of $S$. platensis culture was filtered with Whatman No. 1 filter paper. The filtrate was washed 2 times with distilled water, dried at $80^{\circ} \mathrm{C}$ for $12 \mathrm{~h}$ in cabinet dryer and then dissolved in $1 \mathrm{~mL}$ of distilled water. Frequently diluted $1.6 \mathrm{~g} / \mathrm{L}$ dry biomass of $S$. platensis was used to construct standard curves and calculate the biomass of each sample. The daily dry biomass of $S$. platensis was analyzed using regression analysis base on the equation: $Y_{\text {biomass }}=0.83 X+0.04$ with $\mathrm{R}^{2}=0.9875$.

$Y=$ dry biomass of $S$. platensis

$X=$ optical density at $680 \mathrm{~nm}$ wavelength

\section{Harvest of Spirulina platensis}

Harvesting of S.plantesis was carried out on day 14 by filtering technique using synthetic cloth with a mesh size of $50 \mu \mathrm{m}$ to separate the biomass from the liquid culture. The wet biomass obtained was washed with fresh water and filtered using a synthetic cloth (mesh size $200 \mu \mathrm{m}$ ) to remove salt and dirt. The wet biomass of $S$. platensis was dried at $80^{\circ} \mathrm{C}$ in a drying rack for $12 \mathrm{~h}$ for further analysis of protein, lipid, carbohydrate and chlorophyll content. 


\section{Biochemical composition of Spirulina platensis biomass}

Protein, carbohydrate, lipid and chlorophyll-a content in S. platensis dry biomass were conducted at the initial and the final of cultivation. The total protein analysis refers to the method of Lowry et al. (1951) with a standard solution of bovine serum albumin (BSA). The determination of lipid content in $S$. platensis was conducted by Soxhlet method base on Association of Official Analytical Chemist (AOAC) (2005). The carbohydrate content in S. platensis dry biomass was conducted using method AOAC (2005). The measurement of chlorophyll-a content in $S$. platensis was conducted using Jeffrey and Humphrey (1975) method described by Standard National Indonesia (2010).

\section{Statistical analysis}

Data from all experiments were demonstrated as mean and standard deviation and were analyzed using the Statistical Package for the Social Sciences (SPSS) 21 software. A honestly significant difference (HSD) multiple comparison test was used to determine significant difference among the treatments at $p<0.05$.

\section{Results and Discussion}

\section{Heavy metal concentration in MSGW culture media}

The heavy metal concentration in MSGW culture media of $S$. platensis are presented in table 1 . The MSGW culture medium contained heavy metals $\mathrm{Mg}$, $\mathrm{Fe}, \mathrm{Mn}, \mathrm{Cu}$ and $\mathrm{Zn}$ with various concentrations and the first was $\mathrm{Mg}$ and Fe second. The concentration of each heavy metal significantly $(p<0.05)$ increased with the concentration of MSGW in the culture medium. This is according with Cheng et al. (1996) who reported that MSGW contains 21 metals including heavy metals $\mathrm{Mg}, \mathrm{Fe}, \mathrm{Mn}, \mathrm{Cu}$ and $\mathrm{Zn}$. The results of this study designated that MSGW with the right concentration in the culture medium can support the growth of $S$. platensis by providing a metal component.

It is known that $\mathrm{Cu}$ and $\mathrm{Fe}$ in cells act as components for photosynthetic electron protein transport, $\mathrm{Mn}$ as a photosynthetic water oxidizing center (Andersen, $2005), \mathrm{Zn}$ in carbonic anhydrase as a co-factor for enzymes that amplify in carbon dioxide $\left(\mathrm{CO}_{2}\right)$ fixation (Moroney et al., 2001), $\mathrm{Zn}$ in ribonucleic acid (RNA) polymerase plays a role in deoxyribonucleic acid (DNA) transcription and $\mathrm{Zn}$ in alkaline phosphatase plays a role in the acquisition of phosphorus (Sunda, 2012), Fe in nitrogenase plays a role in dinitrogen $\left(\mathrm{N}_{2}\right)$ assimilation (Bothe et al., 2010) and $\mathrm{Mg}$ as the central element of the chlorophyll molecule (Farhat et al., 2016).

Table-1: Heavy metal content in MSGW culture media of $S$. platensis, the values represent means and standard deviation with different superscript letters in the same column were determined by HSD test and indicate a significantly different $(p<0.05)$.

\begin{tabular}{|c|c|c|c|c|c|}
\hline $\begin{array}{c}\text { Concentration } \\
\text { of MSGW } \\
(\mathbf{m L} / \mathbf{L})\end{array}$ & \multicolumn{4}{|c|}{ Concentration of heavy metal (ppm) } \\
\cline { 2 - 6 } & $\mathbf{M g}$ & $\mathbf{F e}$ & $\mathbf{M n}$ & $\mathbf{C u}$ & $\mathbf{Z n}$ \\
\hline \multirow{2}{*}{1.5} & $904.09 \pm 4$ & $85.06 \pm$ & $8.06 \pm$ & $3.42 \pm$ & $3.69 \pm$ \\
& $01.24^{\mathrm{a}}$ & $13.28^{\mathrm{a}}$ & $2.91^{\mathrm{a}}$ & $1.01^{\mathrm{a}}$ & $1.41^{\mathrm{a}}$ \\
\hline \multirow{2}{*}{2.5} & $1800.18 \pm$ & 153.50 & 11.06 & $5.08 \pm$ & $7.31 \pm$ \\
& $303.32^{\mathrm{b}}$ & $\pm 31.72^{\mathrm{b}}$ & $\pm 2.11^{\mathrm{b}}$ & $1.16^{\mathrm{b}}$ & $4.42^{\mathrm{b}}$ \\
\hline \multirow{2}{*}{3.5} & $3503.23 \pm$ & 253.13 & 13.81 & $7.16 \pm$ & 11.88 \\
& $706.57^{\mathrm{c}}$ & $\pm 30.62^{\mathrm{c}}$ & $\pm 2.17^{\mathrm{c}}$ & $1.24^{\mathrm{c}}$ & $\pm 3.91^{\mathrm{c}}$ \\
\hline \multirow{2}{*}{4.5} & $5708.13 \pm$ & 325.19 & 17.94 & 13.92 & 16.31 \\
& $605.26^{\mathrm{d}}$ & $\pm 36.27^{\mathrm{d}}$ & $\pm 3.42^{\mathrm{d}}$ & $\pm 1.56^{\mathrm{d}}$ & $\pm 5.75^{\mathrm{d}}$ \\
\hline
\end{tabular}

\section{Growth of Spirulina platensis}

Figure-1 shows the growth of $S$. platensis in 5 culture media from the initial to the final of cultivation. The growth of $S$. platensis at the initial of cultivation until the seventh day for all concentrations of MSGW and Walne medium there was no significant difference $(p>0.05)$. Growth of $S$. platensis at the eighth day until the final of culture in MSGW media with concentrations of 1.5 and $4.5 \mathrm{~mL} / \mathrm{L}$ was significantly $(p<0.05)$ lower than 2.5 and $3.5 \mathrm{~mL} / \mathrm{L}$ MGSW and Walne medium. There was no significant $(p>0.05)$ difference in $S$. platensis growth at $2.5 \mathrm{~mL} / \mathrm{L}$ MSGW with Walne medium, but the both were higher than 3.5 $\mathrm{mL} / \mathrm{L}$ MGSW. At the final of culture, S. platensis biomass from Walne medium $(2.91 \pm 0.15 \mathrm{~g} / \mathrm{L})$ did not differ significantly $(p>0.05)$ from the $2.5 \mathrm{~mL} / \mathrm{L}$ MSGW media $(2.87 \pm 0.18 \mathrm{~g} / \mathrm{L})$, but both were significantly $(p<0.05)$ higher than $1.5(1.71 \pm 0.16 \mathrm{~g} / \mathrm{L})$, $3.5(2.54 \pm 0.17 \mathrm{~g} / \mathrm{L})$ and $4.5 \mathrm{~mL} / \mathrm{L}(1.88 \pm 0.19 \mathrm{~g} / \mathrm{L})$. Meanwhile, $S$. platensis from $3.5 \mathrm{~mL} / \mathrm{L}$ MSGW media was significantly $(p<0.05)$ higher than 1.5 and 4.5 $\mathrm{mL} / \mathrm{L}$. There was no significant difference between $S$. platensis biomass from 1.5 and $4.5 \mathrm{~mL} / \mathrm{L}$ MSGW.

Nitrogen, carbon, phosphorus and trace metals is one of the most significant factors that affects the growth parameters and biochemical composition of microalgae (Lin and $\mathrm{Wu}, 2015$ ). In this study, the low growth of $S$. platensis in MSGW medium with a concentration of $1.5 \mathrm{~mL} / \mathrm{L}$ compared to $2.5 \mathrm{~mL} / \mathrm{L}$ and 
Walne medium is thought to be lack of nitrogen and phosphorus. Zeng et al. (2011) suggested that nitrogen is needed for the synthesis of nucleic acids, proteins, pigments such as chlorophyll and phycocyanin, while phosphorous for the formation of DNA and RNA, adenosine triphosphate (ATP), phospholipids. Spirulina productivity is strongly influenced by the concentration and source of nitrogen in the medium (Çelekli and Yavuzatmaca, 2009). The limitation of nitrogen and phosphorus in medium can converts cell from growth to synthesis high molecular contents, such as lipids and carbohydrates (Juneja et al., 2013).

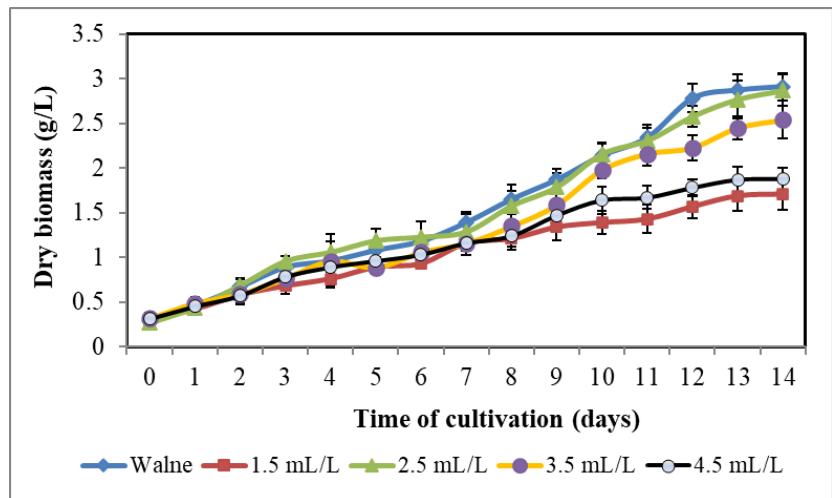

Figure-1: Growth of $S$. platensis in Walne medium and 4 concentration of MSGW during 14 days of cultivation. The values of means and the standard deviation from 5 independent observations

The growth of $S$. platensis in 3.5 and $4.5 \mathrm{~mL} / \mathrm{L}$ MSGW are lower than $2.5 \mathrm{~mL} / \mathrm{L}$ MSGW and Walne medium is thought to the effect of high concentration of ammonium-nitrogen. This study is in accordance with several investigators. Ammonium $\left(\mathrm{N}-\mathrm{NH}_{3}\right)$ is toxic at high concentrations for microalgae because it inhibits photosynthetic equipment, especially electronic transportation in electronic transport chains and nitrate consumption (Khanh et al., 2013). Carvalho et al. (2004) reported that high ammonia concentrations in culture media could inhibit the growth of $S$. platensis. Ammonia can be formed from various nitrogen sources under alkaline conditions through hydrolysis (Danesi et al., 2002) or by urease activity (Shimamatsu, 2004). Yanfeng et al. (2014) reported that MSGW contains high organic matter and ammonia nitrogen. Jiang et al. (2015) reported that high ammonia concentrations (75\% and $100 \%)$ in the MSGW complex medium inhibited the growth of $S$. subsalsa.

In addition, the lower growth of $S$. platensis at concentrations of 3.5 and $4.5 \mathrm{~mL} / \mathrm{L}$ MSGW compared to concentrations of $2.5 \mathrm{~mL} / \mathrm{L}$ MSGW and Walne medium is also thought to be increase in the concentration of heavy metal in media without an increase in rate of aeration and light intensity. Ogbonda et al. (2007) reported that aeration can increase $S$. platensis biomass production. Aeration lay out agitation of growing cells and survives in the suspension of Spirulina species (Dubey, 2006). The aeration rate is in a range that is sufficient to prevent the formation of shear stress in microalgae culture (Zheng et al., 2013). Soni et al. (2019) reported that to obtain biomass, cell productivity, specific growth rate and protein content of $S$. platensis requires adequate aeration, and proper agitation and light intensity. Paes et al. (2016) reported that the availability of nitrogen in high concentrations would result in the growth of Chlorella sp. and Nannochloropsis oculata which is fast if the culture is supplied with sufficient carbon. The high concentration of heavy metals in the media can produce dark areas or light shade that inhibit the photosynthetic process of $S$. platensis. Kula et al. (2017) suggested that density in algae suspensions causes significant changes in the intensity and composition of light reaching individual cells. In photobioreactors, effective mixing ensures spatial homogeneity and avoids the formation of light shade areas by moving cells between the bright light areas and the light shade areas (Giorgia et al., 2018).

The productivity of $S$. platensis in this study was relatively higher than the productivity of some microalgae cultured in wastewater which has been reported by several investigators. Khan et al. (2021) reported that the biomass production of Trichocoleus desertorum cultured in synthetic wastewater was 0.86 g/L/day. Shahid et al. (2021) reported that municipal wastewater can be used as a medium for the cultivation of Plectonema terebrans BERC10 with a dry biomass production of $140 \mathrm{mg} / \mathrm{L} / \mathrm{day}$. Based on the $S$. platensis productivity data in this study, it indicates that MSGW has the potential to be used as a low-cost cultivation medium for microalgae, especially S. platensis. This is in line with Shahid et al. (2021) who reported that urban wastewater can be used as an inexpensive cultivation medium for Acaryochloris marina BERC03, Oscillatoria sp. BERC04, and Pleurocapsa sp. BERC06.

\section{Biochemical composition of Spirulina platensis}

Table-2 shows the protein, lipid, carbohydrate and 
chlorophyll of $S$. platensis from 5 media at the initial and at the final of cultivation. The protein S. platensis at a concentration of $1.5 \mathrm{~mL} / \mathrm{L}$ MSGW decreased by $21.80 \%$, from $54.31 \%$ at the initial of cultivation to $32.51 \%$ at the final of culture. The carbohydrate $S$. platensis at a concentration of $1.5 \mathrm{~mL} / \mathrm{L}$ MSGW decreased from $23.21 \%$ at the initial to $15.73 \%$ at the final of cultivation. The chlorophyll S. platensis at a concentration of $1.5 \mathrm{~mL} / \mathrm{L}$ MSGW decreased from $1.26 \mathrm{mg} / \mathrm{L}$ at the initial to $0.76 \mathrm{mg} / \mathrm{L}$ at the final of cultivation. Next, the lipid $S$. platensis at a concentration of $1.5 \mathrm{~mL} / \mathrm{L}$ MSGW increased from $3.28 \%$ at the initial to $5.73 \%$ at the final of cultivation.

The decrease and low protein, carbohydrate and chlorophyll as well as the increase and high lipid of $S$. platensis at a concentration of $1.5 \mathrm{~mL} / \mathrm{L}$ MSGW are thought to be lack of nitrogen and phosphorus. Uslu et al. (2011) reported that a decrease in nitrogen concentration in the media caused significant changes in cell composition, especially an increase in the accumulation of lipid components and a decrease in protein during the growth of $S$. platensis.

Table-2: Biochemical composition of $S$. platensis from Walne medium and MSGW media at the initial and at the final of cultivation, values represent means and standard deviation with different superscript letters in the same column were determined by HSD test and indicate a significantly different $(p<0.05)$.

\begin{tabular}{|c|c|c|c|c|c|}
\hline \multirow{2}{*}{$\begin{array}{c}\text { Concentr } \\
\text { ation of } \\
\text { MSGW } \\
(\mathrm{mL} / \mathrm{L})\end{array}$} & \multirow[b]{2}{*}{$\begin{array}{c}\text { Stage of } \\
\text { cultivati } \\
\text { on }\end{array}$} & \multicolumn{4}{|c|}{ Biochemical composition of $S$. platensis } \\
\hline & & $\begin{array}{c}\text { Protein } \\
(\%)\end{array}$ & $\begin{array}{c}\text { Lipid } \\
(\%)\end{array}$ & $\begin{array}{c}\text { Carbohy } \\
\text { drate }(\%)\end{array}$ & $\begin{array}{c}\text { Chlorop } \\
\text { hyll } \\
(\mathrm{mg} / \mathrm{g})\end{array}$ \\
\hline \multirow{2}{*}{0 (Walne) } & Initial & $\begin{array}{c}53.70 \pm \\
10.08\end{array}$ & $\begin{array}{c}3.19 \pm \\
0.38\end{array}$ & $\begin{array}{c}22.39 \pm \\
3.38\end{array}$ & $\begin{array}{c}1.29 \pm \\
0.08\end{array}$ \\
\hline & Final & $\begin{array}{c}54.94 \pm \\
7.82^{c}\end{array}$ & $\begin{array}{l}3.32 \pm \\
0.47^{\mathrm{a}}\end{array}$ & $\begin{array}{c}21.68 \pm \\
3.04^{\mathrm{b}}\end{array}$ & $\begin{array}{l}1.23 \pm \\
0.07^{b}\end{array}$ \\
\hline \multirow{2}{*}{1.5} & Initial & $\begin{array}{c}54.31 \pm \\
9.05\end{array}$ & $\begin{array}{c}3.28 \pm \\
0.27\end{array}$ & $\begin{array}{c}23.51 \pm \\
3.27\end{array}$ & $\begin{array}{c}1.26 \pm \\
0.08\end{array}$ \\
\hline & Final & $\begin{array}{c}32.51 \pm \\
6.22^{\mathrm{a}}\end{array}$ & $\begin{array}{l}5.73 \pm \\
0.86^{\mathrm{b}}\end{array}$ & $\begin{array}{c}15.73 \pm \\
3.66^{\mathrm{a}}\end{array}$ & $\begin{array}{l}0.76 \pm \\
0.08^{\mathrm{a}}\end{array}$ \\
\hline \multirow{2}{*}{2.5} & Initial & $\begin{array}{c}54.28 \pm \\
11.07\end{array}$ & $\begin{array}{c}3.31 \pm \\
0.25\end{array}$ & $\begin{array}{c}23.67 \pm \\
3.25\end{array}$ & $\begin{array}{c}1.28 \pm \\
0.12\end{array}$ \\
\hline & Final & $\begin{array}{l}53.25 \pm \\
13.48^{c}\end{array}$ & $\begin{array}{l}3.45 \pm \\
0.46^{\mathrm{a}}\end{array}$ & $\begin{array}{c}21.83 \pm \\
2.46^{\mathrm{b}}\end{array}$ & $\begin{array}{l}1.22 \pm \\
0.09^{b}\end{array}$ \\
\hline \multirow{2}{*}{3.5} & Initial & $\begin{array}{c}53.32 \pm \\
8.05\end{array}$ & $\begin{array}{c}3.27 \pm \\
0.14\end{array}$ & $\begin{array}{c}23.43 \pm \\
3.14\end{array}$ & $\begin{array}{c}1.27 \pm \\
0.09\end{array}$ \\
\hline & Final & $\begin{array}{l}49.63 \pm \\
10.42^{c}\end{array}$ & $\begin{array}{l}5.81 \pm \\
0.86^{\mathrm{b}}\end{array}$ & $\begin{array}{c}19.87 \pm \\
2.69^{b}\end{array}$ & $\begin{array}{l}1.06 \pm \\
0.07^{b}\end{array}$ \\
\hline \multirow{2}{*}{4.5} & Initial & $\begin{array}{c}52.17 \pm \\
13.23\end{array}$ & $\begin{array}{c}3.32 \pm \\
0.35\end{array}$ & $\begin{array}{c}21.58 \pm \\
3.35\end{array}$ & $\begin{array}{c}1.24 \pm \\
0.14\end{array}$ \\
\hline & Final & $\begin{array}{l}43.28 \pm \\
12.13^{b}\end{array}$ & $\begin{array}{l}6.16 \pm \\
0.92^{b}\end{array}$ & $\begin{array}{c}17.65 \pm \\
3.92^{\mathrm{a}}\end{array}$ & $\begin{array}{l}0.98 \pm \\
0.08^{\mathrm{ab}}\end{array}$ \\
\hline
\end{tabular}

The nitrogen source and concentration influence the accumulation of lipid in S. platensis (Nyabuto et al., 2015). Yilancioglu et al. (2014) reported that nitrogen deficiency can cause oxidative stress and lipid accumulation in microalgae cells. Wang et al. (2014) published that nitrogen deficiency in the media for a long time causes a reduction in photosynthetic efficiency, thus, cells begin to metabolize carbohydrates as energy and carbon source. Menegol et al. (2017) reported that carbohydrate synthesis by microalgae was influenced by nitrogen concentration. The chlorophyll of $S$. platensis is determined by the nutrient, light and temperature (Danesi et al., 2011). Chlorophyll is an easily accessible nitrogen-rich component and is an intracellular nitrogen pool for growth support (Li et al., 2008). The synthesis of chlorophyll and carotenoid depends on mineral nutrition (Daughtry et al., 2000) and phosphorus is one of the components necessary for the growth and development of algae cells (Hu, 2004). Phosphorus takes part in many metabolic processes, such as signal transduction, energy conversion and photosynthesis (Navarro et al., 2008).

The protein content in $S$. platensis at a concentration of $4.5 \mathrm{~mL} / \mathrm{L}$ MSGW decreased by $8.89 \%$, at the initial of cultivation $52.17 \%$ to $43.28 \%$ at the final of cultivation. The carbohydrate $S$. platensis at a concentration of $4.5 \mathrm{~mL} / \mathrm{L}$ MSGW decreased from $21.58 \%$ at the initial to $17.65 \%$ at the final of cultivation. The chlorophyll $S$. platensis at a concentration of $4.5 \mathrm{~mL} / \mathrm{L}$ MSGW decreased from $1.24 \mathrm{mg} / \mathrm{g}$ at the initial to $0.98 \mathrm{mg} / \mathrm{g}$ at the final of cultivation. Meanwhile, the lipid $S$. platensis at concentrations of $4.5 \mathrm{~mL} / \mathrm{L}$ MSGW increased from $3.32 \%$ at the initial to $6.16 \%$ at the final of cultivation.

The lower protein and carbohydrate content as well as higher lipids content in $S$. platensis at a concentration of $4.5 \mathrm{~mL} / \mathrm{L}$ MSGW compared to $2.5 \mathrm{~mL} / \mathrm{L}$ MSGW and Walne medium are thought to be increase MSGW concentrations without followed by increasing rate of aeration in culture. This study designates that the aeration rate of $0.7 \mathrm{~L} / \mathrm{L} / \mathrm{min}$ is inadequate at concentration of $4.5 \mathrm{~mL} / \mathrm{L}$ MSGW to produce high growth and content of protein, and carbohydrate in $S$. platensis. Ogbonda et al. (2007) reported that aeration can increase protein synthesis by $S$. platensis. Fábregas et al. (1995) reported that the aeration rate can increase carbohydrate and protein content in microalgae. Regarding the effects of aeration on microalgae lipid 
content there are differences between investigators. Zheng et al. (2012) reported that the rate of aeration can increase lipid production of $C$. vulgaris. Meanwhile, Shirzadi et al. (2017) reported that aeration rate had no effect on the content of lipid $C$. vulgaris. Observations of low chlorophyll S. platensis at concentrations of 3.5 and $4.5 \mathrm{~mL} / \mathrm{L}$ MSGW confirmed that high concentrations of heavy metals in the media could inhibit $S$. platensis growth because the rate of photosynthesis was inhibited by the appearance of the light shade areas in the photobioreactor.

Table-3: Nitrogen and phosphorus contents in $S$. platensis culture media at the initial and at the final of cultivation, values represent means and standard deviation with different superscript letters in the same column were determined by HSD test and indicate a significantly different $(p<0.05)$.

\begin{tabular}{|c|c|c|c|c|}
\hline \multirow{2}{*}{$\begin{array}{c}\text { Concentratio } \\
\mathrm{n} \text { of MSGW } \\
(\mathrm{mL} / \mathrm{L})\end{array}$} & \multicolumn{2}{|c|}{ Nitrogen $(\%)$} & \multicolumn{2}{|c|}{ Phosphorus (\%) } \\
\hline & Initial & Final & Initial & Final \\
\hline 0 (Walne) & $\begin{array}{l}4.01 \pm \\
0.43^{\mathrm{b}}\end{array}$ & $\begin{array}{l}0.65 \pm \\
0.18^{\mathrm{a}}\end{array}$ & $\begin{array}{l}0.085 \pm \\
0.012^{b}\end{array}$ & $\begin{array}{l}0.014 \pm \\
0.008^{\mathrm{a}}\end{array}$ \\
\hline 1.5 & $\begin{array}{l}1.29 \pm \\
0.29^{\mathrm{a}}\end{array}$ & $\begin{array}{c}\text { no } \\
\text { detection }\end{array}$ & $\begin{array}{l}0.046 \pm \\
0.018^{\mathrm{a}}\end{array}$ & $\begin{array}{c}\text { no } \\
\text { detection }\end{array}$ \\
\hline 2.5 & $\begin{array}{l}3.85 \pm \\
0.36^{\mathrm{b}}\end{array}$ & $\begin{array}{c}0.62 \pm \\
0.14^{\mathrm{a}}\end{array}$ & $\begin{array}{l}0.092 \pm \\
0.021^{b}\end{array}$ & $\begin{array}{c}0.019 \pm \\
0.007^{\mathrm{a}}\end{array}$ \\
\hline 3.5 & $\begin{array}{l}4.52 \pm \\
0.34^{c}\end{array}$ & $\begin{array}{l}1.58 \pm \\
0.19^{b}\end{array}$ & $\begin{array}{l}0.136 \pm \\
0.034^{\mathrm{c}}\end{array}$ & $\begin{array}{l}0.047 \pm \\
0.012^{b}\end{array}$ \\
\hline 4.5 & $\begin{array}{l}6.32 \pm \\
0.72^{\mathrm{d}}\end{array}$ & $\begin{array}{l}3.24 \pm \\
0.15^{\mathrm{b}}\end{array}$ & $\begin{array}{l}0.163 \pm \\
0.046^{\mathrm{d}}\end{array}$ & $\begin{array}{l}0.068 \pm \\
0.015^{\mathrm{c}}\end{array}$ \\
\hline
\end{tabular}

\section{Nitrogen and phosphorus uptake}

Analysis of nitrogen and phosphorus content in 5 media at initial and final cultivation of $S$. platensis are presented in Table 3. Nitrogen available in Walne medium, 2.5, 3.5 and $4.5 \mathrm{~mL} / \mathrm{L}$ MSGW media were uptaken as much $83.79,83.90,65.04$ and $48.73 \%$, respectively. Meanwhile, phosphorus available in Walne medium, 2.5, 3.5 and $4.5 \mathrm{~mL} / \mathrm{L}$ MSGW media were uptaken as much 83.53, 79.35, 65.44 and $58.28 \%$, respectively. The decrease of nitrogen and phosphorus content in the media after culture is due to the use of nitrogen and phosphorus by S. platensis for growth and other activities. Nitrogen and phosphorus are the main limiting nutrients for aquatic algae production due to their short supply compared to the needs of cellular growth (Jin et al., 2011). Nitrogen is an element and component of protein, chlorophyll and DNA, plays an important role in the culture of microalgae (Zarrinmehr et al., 2019). Some metabolic processes of microalgae such as signal transduction, energy conversion and photosynthesis involve the role of phosphorus (Navarro et al., 2008). These observations of nitrogen and phosphorus uptake confirmed that growth and changes in the constituent's composition of $S$. platensis at a concentration of $1.5,3.5$ and $4.5 \mathrm{~mL} / \mathrm{L}$ MSGW media are caused by a lack or excess content of ammoniumnitrogen and phosphorus in the media than necessary at culture condition. The high nitrogen and phosphorus residues in 3.5 and $4.5 \mathrm{~mL} / \mathrm{L}$ MSGW were suspected because the aeration rate of the culture media used in this study was inadequate at this concentration to produce a uniform distribution of $S$. platensis cells and nutrient media. Khoo et al. (2017) reported that an increase in compressed aeration flow rates increases the biomass dry weight yield because it provides a well-mixed environment for $C$. vulgaris growth.

\section{Conclusion}

This study leads to the conclusion that MSGW can provide nutrient components such as nitrogen, phosphate and heavy metals that are potentially used as $S$. platensis culture media to reduce production costs. Setting the concentration of MSGW in culture media and conditions of culture such as light intensity and aeration needs to be done to obtain the maximum $S$. platensis production performance. The optimum concentration of MSGW in the media is 2.5 $\mathrm{mL} / \mathrm{L}$. MSGW has high potential to be used as a medium-cost source of low-cost nutrition for $S$. platensis on a large scale in the future. The use of MSGW on a large scale can have an impact on reducing wastewater pollution, specifically the waste from the MSG food flavoring factory.

\section{Acknowledgement}

All authors would like to thank the Microbiology Laboratory, Faculty of Sciences and Technology, University of PGRI Adi Buana Surabaya for the support of research provision.

Disclaimer: None.

Conflict of Interest: None. Source of Funding: None. 


\section{References}

American Society of Agronomy and Soil Science Society of America, 1982. Methods of Soil Analysis. 2nd edn. Part 2. In Chemical and Microbiological Properties eds. Page. A.L., Miller. R.H. and Keeney. D.R. pp. 649-670. Madison. WI: American Society of Agronomy and Soil Science Society of America.

Andersen RA, 2005. Algal culturing techniques. Academic Press, Elsevier Science. San Diego, California, USA.

Association of Official Analytical Chemist [AOAC], 2005. Official Methods of Analysis (18 Edn). Association of Official Analytical Chemist Inc., Mayland, USA.

Bothe H, Schmitz O, Yates MG and Newton WE, 2010. Nitrogen fixation and hydrogen metabolism in cyanobacteria. Microbiol. Mol. Biol. Rev. 74:529551.

Cai T, Park SY and Li Y, 2013. Nutrient recovery from wastewater streams by microalgae: status and prospects. Renew. Sustain. Energ. Rev. 19:360-369.

Carvalho JCM, Francisco FR, Almeida KA, Sato S and Converti A, 2004. Culture of Arthrospira (Spirulina) platensis (Cyanophyceae) by fed-batch addition of ammonium chloride at exponentially increasing feeding rates. J. Phyco. 40:589-597.

Çelekli A and Yavuzatmaca M, 2009. Predictive modeling of biomass production by Spirulina platensis as function of nitrate and $\mathrm{NaCl}$ concentrations. Biores. Technol. 100:1847-1851.

Cheng SP, Liu YB, Cui YB, Ding SR and Shi YZ, 1996. Effects of Monosodium Glutamate Wastewater on the Fish Ctenopharyngodon idellus and the Cabbage Brassica capestris. Bull. Environ. Cont. Toxicol. 57(6):972-978.

Citra Cendikia Indonesia, 2021. Produsen dan Kapasitas Produksi MSG di Indonesia.. https://cciindonesia.com/produsen-dan-kapasitas-produksimsg-di-indonesia/

Danesi EDG, Rangel-Yagui CO, Carvalho JCM and Sato S, 2002. An investigation of effect of replacing nitrate by urea in the growth and production of chlorophyll by Spirulina platensis. Biomass Bioenerg. 23:261-269.

Danesi EDG, Rangel-Yagui CO, Sato S and Carvalho JCM, 2011. Growth and Content of Spirulina Platensis Biomass Chlorophyll Cultivated at Different Values of Light Intensity and Temperature Using Different Nitrogen Sources. Braz. J. Microbiol. 42(1): 362-373.

Daughtry CST, Walthall CL, Kim MS, Brown de
Colstoun E and McMurtrey JE, 2000. Estimating corn leaf chlorophyll concentration from leaf and canopy reflectance. Remote Sens. Environ. 74(2):229-239.

Delrue F, Alaux E, Moudjaoui L, Gaignard C, Fleury G, Perilhou A, Richaud P, Petitjean M and Sassi JF, 2017. Optimization of Arthrospira platensis (Spirulina) Growth: From Laboratory Scale to Pilot Scale. Fermentation. 3(59):1-14.

Dubey RC, 2006. A textbook of Biotechnology. Fourth revised and enlarged edition. S. Chand \& Co. P Ltd, New Delhi, India.

Fábregas J, Ferrón L, Abalde J, Cabezas B and Otero A, 1995. Changes in the gross chemical composition of mass cultures of the marine microalga Dunaliella tertiolecta with different aeration rates. Biores. Technol. 53(2):185-188

Farhat N, Elkhouni A, Zorrig W, Smaoui A, Abdelly C and Rabhi M, 2016. Effects of magnesium deficiency on photosynthesis and carbohydrate partitioning. Acta Physiol. Plant. 38(6):145

Fithriani D and Sinurat E, 2019. Utilization of spirulina as functional food: Phytosterol and amino acid profiles study. IOP Conf. Ser.: Earth Environ. Sci. 278012028.

Food and Agriculture Organization (FAO), 2009. A third more mouths to feed. http://www.fao.org/news/story/en/item/35571/icode I

Giorgia S, Agneseb C and Marcoa B, 2018. Growth of Microalgae in Spectrum-Neutral, Volume Distributed Light Restriction as the Baseline of Wastewater Exploitation. Chem. Eng. Trans. 64:16.

Habib MAB, Parvin M, Huntington TC and Hasan MR, 2008. A review on culture, production and use of spirulina as food for humans and feeds for domestic animals and fish. FAO Fisheries and Aquaculture Circular. No. 1034. Rome, Italy.

Haghighi M, Fang P and Pessarakli M, 2015. Effects of Ammonium Nitrate and Monosodium Glutamate in Waste Water on the Growth, Antioxidant Activity, and Nitrogen Assimilation of Lettuce (Lactuca sativa L.). J. Plant Nutr. 38(14):2217-2229.

$\mathrm{Hu}$ Q, 2004. Environmental Effects on Cell Composition. In Handbook of Microalgal Culture: Biotechnology and Applied Phycology; Richmond. A., Ed.; Blackwell: Oxford. UK.

Jeffrey SW and Humphrey GF, 1975. New spectrophotometric equations for determining chlorophyll a. b c1 and c2 in higher plants. algae and natural phytoplankton. Biochemie und Physiologie der Pflanzen. 167(2):191-194. 
Jiang L, Pei H, Hu W, Ji Y, Han L and Ma G, 2015. The feasibility of using complex wastewater from a monosodium glutamate factory to cultivate Spirulina subsalsa and accumulate biochemical composition. Biores. Technol. 180:304-310.

Jin Lv, Wu H and Chen M, 2011. Effects of nitrogen and phosphorus on phytoplankton composition and biomass in 15 subtropical, urban shallow lakes in Wuhan, China. Limnologica. 41(1):48-56.

Juneja A, Ceballos RM and Murthy GS, 2013. Effects of environmental factors and nutrient availability on the biochemical composition of algae for biofuels production: A review. Energies. 6(9):4607-4638.

Khan F, Malik S, Shahid A, Siddiqui AJ, Musharraf SG, Zhu H, Alkhattabi NA, Gull M and Mehmood MA, 2021. Characterization of a newly isolated cyanobacterium Trichocoleus desertorum BERC08 as a potential feedstock for the algal biorefinery. Biomass Conv. Bioref. (2021). https://doi.org/10.1007/s13399-021-01537-3

Khanh N, Kitaya Y, Xiao L, Finalo R and Shibuya T, 2013. Selection of microalgae suitable for culturing with digestate from methane fermentation. Environ. Technol. 34:2039-2045.

Khoo CG, Woo MH, Yury N, Lam MK and Lee KT, 2017. Dual role of Chlorella vulgaris in wastewater treatment for biodiesel production: Growth optimization and nutrients removal study. J-Stage. 96 (8):290-299.

Kula M, Kalaji M and Skoczowski A, 2017. Culture density influence on the photosynthetic efficiency of microalgae growing under different spectral compositions of light. J. Photochem. Photobiol. B. 167: 290-298.

Li Y, Horsman M, Wang B, Wu N and Lan CQ, 2008. Effects of nitrogen sources on cell growth and lipid accumulation of green alga Neochloris oleoabundans. Appl. Microbiol.

Biotechnol. 81: 629-636.

Lin TS and Wu JY, 2015. Effect of carbon sources on growth and lipid accumulation of newly isolated microalgae cultured under mixotrophic condition. Bioresour. Technol. 184:100-107.

Lowry OH, Rosebrough NJ, Farr AL and Randall RJ, 1951. Protein measurement with the folin phenol reagent. J. Biol. Chem. 193:265-275.

Madkour FF, Kamil AW and Nasr HS, 2012. Production and nutritive value of Spirulina platensis in reduced cost media. The Egypt J. Aqua. Res. 38(1):51-57.

Markou G and Nerantzis E, 2013. Microalgae for highvalue compounds and biofuels production: a review with focus on culture under stress conditions. Biotechnol. Adv. 8:1532-1542.

Menegol T, Diprat AB, Rodrigues E and Rech R, 2017. Effect of temperature and nitrogen concentration on biomass composition of Heterochlorella luteoviridis. Food Sci. Technol. 37(spe):28-37. DOI:10.1590/1678-457x.13417

Moroney JV, Bartlett SG and Samuelsson G, 2001. Carbonic anhydrases in plants and algae. Plant Cell Environ. 24:141-153.

Mourelle ML, Gómez CP and Legido JL, 2017. Review: The Potential Use of Marine Microalgae and Cyanobacteria in Cosmetics and Thalassotherapy. Cosmetics. 4(4): 46-78.

Navarro E, Baun A, Behra R, Hartmann NB, Filser J, Miao AJ, Quigg A, Santschi PH and Sigg L, 2008. Environmental behavior and ecotoxicity of engineered nanoparticles to algae, plants, and fungi. Ecotoxicol. 17(5):372-386.

Nyabuto DK, Cao K, Mariga AM, Kibue GW, He M and Wang C, 2015. Growth performance and biochemical analysis of the genus Spirulina under different physical and chemical environmental factors. Afric. J. Agric. Res. 10(36):3614-3624.

Ogbonda KH, Aminigo RE, Gideon O and Abu GO, 2007. Influence of aeration and lighting on biomass production and protein biosynthesis in a Spirulina sp. Isolated from an oil-polluted brackish water marsh in the Niger Delta. Nigeria. Afr. J. Biotechnol. 6(22):2596-2600.

Paes CRPS, Faria GR, Tinoco NAB, Castro DJFA, Barbarino E and Lourencol SO, 2016. Growth. nutrient uptake and chemical composition of Chlorella sp. and Nannochloropsis oculata under nitrogen starvation. Lat. Am. J. Aqua. Res. 44(2): 275-292.

Pareek R, 2016. Algae: The future food supplement. Int. J. Food Agric. Vet. Sci. 6(1):74-77.

Prabha Y, Tyagi A and Soni SK, 2016. Impact of Monosodium glutamate on the production and chemical constituents of Spirulina maxima. Int. J. Pure Appll. Biosci. 4(1):180-184.

Rahman MA, Aziz MA, Al-khulaidi RA, Sakib N and Islam M, 2017. Biodiesel production from microalgae Spirulina maxima by two step process: Optimization of process variable. J. Radia. Res. Appll. Sci. 10(2):140-147.

Samudera SM and Sopandi T, 2020. Protein, fat, and carbohydrate content in Spirulina platensis biomass cultivated on quail manure based media. Stigma. 13(02):22-28.

Shahid A, Malik S, Liu CG, Musharraf SG, Siddiqui AJ, Khan F, Tarbiah NI, Gull M, Rashid U and 
Mehmood MA, 2021. Characterization of a newly isolated cyanobacterium Plectonema terebrans for biotransformation of the wastewater-derived nutrients to biofuel and high-value bioproducts. J. Water Process. Eng. 39:101702. https://doi.org/10.1016/j.jwpe.2020.101702

Shahid A, Usman M, Atta Z, Musharraf SG, Malik S, Elkamel A, Shahid M, Alkhattabi NA, Gull M and Mehmood MA, 2021. Impact of wastewater cultivation on pollutant removal, biomass production, metabolite biosynthesis, and carbon dioxide fixation of newly isolated cyanobacteria in a multiproduct biorefinery paradigm. Biores. Technol. 333 : 125194. http://doi.org/10.1016/j.biortech.2021.125194

Shimamatsu H, 2004. Mass production of Spirulina. an edible microalga. Hydrobiologia. 512:39-44.

Shirzadi A, Gheshlaghi R and Mahdavi MA, 2017. The Effect of aeration rate on growth and lipid content of Chlorella vulgaris microalgae in a flat plate photobioreactor. $1^{\text {st }}$ International Joint Conference on New Trends in Biotechnology, Zahidan, Iran. https://profdoc.um.ac.ir/paper-abstract1062924.html

Singh S, Rekha PD, Arun AB, Huang YM, Shen FT and Young CC, 2011. Wastewater from monosodium glutamate industry as a low cost fertilizer source for corn (Zea mays L.). Biomass Bioenerg. 35(9):40014007

Smith R, 1983. A laboratory manual for the determination of metals in water and wastewater by atomic absorption spectrophotometry. National Institute For Water Research Council For Scientific and Industrial Research, Pretoria, South Africa. CSIR Technical Guide K63.

Soelaeman Y, Wahyunto and Sunaryo, 2004. The Use of Mono Sodium Glutamate (MSG) Liquid Waste for Food Crops in Lampung. Soil Research Institute, Bogor. 123-142. http://balittanah.litbang.pertanian.go.id/ind/dokume ntasi/prosiding/mflp2004/yoyo\%20sulaeman.pdf

Soni RA, Sudhakar K and Rana RS, 2019. Comparative study on the growth performance of Spirulina platensis on modifying culture media. Energy Reports. 5. November; 327-336.

Sopandi T, Rohmah S and Agustina SAT, 2020. Biomass and nutrient composition of Spirulina platensis grown in goat manure media. Asian $\mathrm{J}$. Agric. Biol. 8(2):158-167.

Standard National Indonesia [SNI], 2010.
Determination of Total Phosphorus Content. SNI 2803:2010. Badan Standarisasi Nasional, ICS 13.060.01. Jakarta, Indonesia.

Sunda WG, 2012. Feedback interactions between trace metal nutrients and phytoplankton in the ocean. Front. Microbiol. 3(204):1-22.

Uslu LH, Işik O, Koç $\mathrm{K}$ and Göksan T, 2011. The effects of nitrogen deficiencies on the lipid and protein contents of Spirulina platensis. Afr. J. Biotechnol. 10(3): 386-389.

Vonshak A, 1997. Spirulina: growth. physiology and biochemistry. In: Vonshak A (ed) Spirulina platensis (Arthrospira): physiology. cell-biology and biotechnology. Taylor and Francis. London, UK.

Wang W, Han F, Li Y, Wu Y, Wang J, Pan R and Shen G, 2014. Medium screening and optimization for photoautotrophic culture of Chlorella pyrenoidosa with high lipid productivity indoors and outdoors. Biores. Technol.170:395-403.

Yap PY, Jain A and Trau D, 2018. Determination of biomass in Spirulina cultures by photopette. Life Science Application Note 050. Version 1 February 2018. 1-3. http://tipbiosystems.com/tbs/wpcontent/uploads/2019/03/AN50-Spirulinabiomass_2018_02_02.pdf

Yanfeng Z, Fugui Z, Lu L and Heilongjiang, 2014. Study on Treatment Technology of Monosodium Glutamate Waste Water. Environ. Sci. Manage. 2014-07.

Yilancioglu K, Cokol M, Pastirmaci I, Erman B and Cetiner S, 2014. Oxidative stress is a mediator for increased lipid accumulation in a newly isolated Dunaliella salina strain. PLoS ONE. 9(3): e91957.

Zarrinmehr MJ, Farhadian O, Heyrati FP, Keramat J, Koutra E, Kornaros M and Daneshvar E, 2019. Effect of nitrogen concentration on the growth rate and biochemical composition of the microalga. Isochrysis galbana. The Egypt. J. Aqua. Res. 46 (2), 153-158, 2020.

Zeng X, Danquah MK, Chen XD and Lu Y, 2011. Microalgae bioengineering: From $\mathrm{CO}_{2}$ fixation to biofuel production. Renew. and Sustain. Energy Rev. 15(6):3252-3260.

Zheng H, Gao Z, Yin F, Ji X and Huang H, 2012. Effect of $\mathrm{CO}_{2}$ supply conditions on lipid production of Chlorella vulgaris from enzymatic hydrolysates of lipid-extracted microalgal biomass residues. Biores. Technol.126:24-30. 
Zheng Y, Chen Z, Lu H and Zhang W, 2013. Optimization of carbon dioxide fixation and starch accumulation by Tetraselmis subcordiformis In a rectangular airlift photobioreactor. Afr. J. Biotechnol.10:1888-1901.

\section{Contribution of Authors}

Wardah W: Data collection and analysis of heavy metal content in the media as well as helping to write article.

Nurhayati F: Data collection and analysis of $S$. platensis biomass composition and helped write article

Magdalena MM: Data collection and analysis of nitrogen and phosphorus content of $S$. platensis biomass and helped write article.

Fazilah N \& Sopandi T: Coordinated research activity, cultivation and growth observations of $S$. platensis and wrote article. 